ISSN 0258-7122 (Print), 2408-8293 (Online)

Bangladesh J. Agril. Res. 44(2): 339-353, June 2019

\title{
EFFICACY OF DIFFERENT MANAGEMENT PRACTICES AGAINST TOMATO FRUIT BORER, Helicoverpa armigera Hubner
}

\author{
M. M. KAMAL ${ }^{1}$, S. DAS ${ }^{2}$, M. H. SABIT ${ }^{3}$ AND D. DAS ${ }^{4}$
}

\begin{abstract}
The study was conducted to evaluate the efficacy of different management practices to control tomato fruit borer (TFB) under field condition. The field experiment was carried out with eight treatments, namely Neem oil, Mahogany oil, Fish and Fermented Gur (brown sugar), Netting, Chlorpyriphos, Emamectin Benzoate and Cartap along with untreated control in Randomized Complete Block Design (RCBD) and each treatment was replicated thrice. The study was under taken during the period from 25 October, 2017 to 06 April 2018. Data were collected on number and weight of total fruits plot $^{-1}$, number and weight of total healthy fruits plot $^{-1}$, number and weight of total infested fruits plot $^{-1}$, fruits infestation (\%) in number and weight, infestation reduction over control for number and weight, number of holes, and larvae plot $^{-1}$, total yield plot $^{-1}$ and marketable yield plot $^{-1}$. Among the different management practices, netting provided the highest infestation reduction over control. The percent fruit infestation reduction over control (number basis) was the highest in Netting treated plot resulting $61.87 \%, 73.27 \%, 84.68 \%$ and $92.70 \%$ at four different harvests, respectively. The percent fruit infestation reduction over control (weight basis) was the highest with the same treatment resulting $61.38 \%$, $74.26 \%, 88.41 \%$ and $91.71 \%$ at four different harvests, respectively. The number of holes plot ${ }^{-1}$ was also the lowest in Netting treated plot resulting 5.00, $8.00,15.33$ and 8.67 at four different harvests, respectively. The number of larvae plot $^{-1}$ was the lowest with the same treatment resulting 2.00, 2.33, 3.67 and 3.00 at four different harvests, respectively. The maximum marketable yield (33.95 $\left.\mathrm{t} \mathrm{ha}^{-1}\right)$ was achieved in the Emamectin Benzoate treated plot with the highest (1.46) benefit cost ratio.
\end{abstract}

Keywords: Tomato fruit borer, Infestation reduction, Management practices, Effectiveness.

\section{Introduction}

In Bangladesh vegetables are cultivated about in 414980 ha of the total cultivable land and its production was $4.05 \mathrm{~m}$ metric tons during the crop year 2016-17 where ha ${ }^{-1}$ yield was $9754.03 \mathrm{t}(\mathrm{BBS}, 2017)$ due to favourable soil and climatic condition.

Among vegetables tomato is one of the most important crop after potato belongings to the family Solanaceae and genus Solanum. Itis native to Peruvian and Mexican region which is herbaceous in nature. A good commercial yield

${ }^{1-4}$ Agrotechnology Discipline, Khulna University, Khulna-9208, Bangladesh. 
under irrigation is 45 to 65 tha $^{-1}$ of fresh fruit (FAOSTAT, 2001). In Bangladesh, tomato is cultivated in about 27530 haof the total cultivable land of all vegetables and its yield was $0.37 \mathrm{~m}$ metric tons during the crop year of 2016-17 where ha ${ }^{-1}$ yield was $14044.42 \mathrm{t}$ (BBS, 2017) which is very low to fulfill the demand of the country.

In terms of nutrition, tomato contains double amount of nutritive elements compared to apple. It is the cheapest source of vitamins (A, B and C), minerals like calcium and proteins which majority of people can buy easily (Bose and Som, 1990; Pedro and Ferreira, 2007). Lycopene in ripe tomato is a potential antioxidant which reduces the risk of prostate cancer of human (Hossain et al., 2004). Regular consumption of tomatoes can prevent short sightedness, night blindness, and other eye diseases. It is also helpful in preventing joint pain problems and the respiratory disorder as well (Friedman, 2013).

Generally, rabi season is suitable for tomato cultivation in Bangladesh but it has also great potentiality to grow in summer because of its photo insensitiveness. There are several reasons behind low production of tomato like insect infestation anddiseases. Generally tomato plant is affected by various types of insects, among them; tomato fruit borer (Helicoverpa armigera)causes devastating loss to tomato. It is polyphagous insect and attacks tomato, eggplant, cotton, tobacco, maize, sorghum, various legumes, okra, pepper and other horticultural crops. It reduces the yield as well as quality drastically (Wagh et al., 2012).

Damage mainly caused by larvae from seedling to fruiting stage to tomato plant as they feed on the seeds and flesh, and moth damage the host plant foliage mainly by ovipositional activities. Larvae also make holes, when they emerge which can provide a pathway for disease-causing micro-organisms (Shah et al., 2013). Larval damage makes the fruits unmarketable and unfit for human consumption and also responsible for decreasing the seed viability compared to undamaged fruit (Karabhantanal and Awaknavar, 2013).

Many prohibitive measures have been introduced to control the tomato fruit borer across the world. The research work of non-chemical control is not abundant. Generally the farmer of globe use chemical insecticides to control this pest and Bangladesh is not exception due to their easy availability and applicability. Though the rapid action of chemical insecticides, but they have extreme adverse effects on environment and consumers. Moreover, indiscriminate use of chemical insecticides for controlling insect pest of crop plant resulted hazardous effects causing serious problems including pest resistance, pest outbreak, pest resurgence and environmental pollution (Geiger et al., 2010).

Entomologistsare giving great emphasis on IPM practices. Now-a-days different eco-friendly control approaches like botanicals, netting, pheromone etc. are widely used to avoid the hazardous effect on environment. But the researches on the effectiveness of different management practices against TFB for sustainable 
vegetable production in Bangladesh are not adequate as expected. In these circumstances, the present research was undertaken to evaluate the effectiveness of some management practices against TFB and to select the cost effective management practices.

\section{Materials and methods}

\section{Experimental site and climatic condition}

The experiment was conducted at the Field Laboratory of Agrotechnology Discipline, Khulna University, Khulna $\left(22^{\circ} 47^{\prime} 57.84^{\prime \prime} \mathrm{N} \quad 89^{\circ} 31^{\prime} 53.48^{\prime \prime} \mathrm{E}\right)$, Bangladeshbelonging to the Agro-ecological Zone "AEZ-13" (Ganges Tidal Floodplain) during 25 October, 2017 to 06 April 2018. The site was characterized by moderately high temperature and heavy rainfall during kharif season (AprilOctober) and scantly rainfall with moderately low temperature during rabi season (November-March).

\section{Raising of seedlings, setting experiment and transplanting}

The seed of BARI Tomato 14 was collected from Bangladesh Agricultural Research Institute (BARI), Gazipur and seedling was raised in germplasm centre of Khulna University. Tomato seedling was raised in seedbed of $3 \mathrm{~m} \times 1 \mathrm{~m}$ size. Weeding, mulching and irrigation were done when required. The experiment was laid out in the Randomized Complete Block Design (RCBD) with three replications. The entire experimental plot was divided into 3 blocks each containing 8 units plots. In total there were 24 unit plots. The treatments were randomly assigned to each unit plot so as to allot one treatment once in each block. The unit plots were $2.5 \mathrm{~m} \times 2 \mathrm{~m}$ with $50 \mathrm{~cm}$ distance between the blocks and $40 \mathrm{~cm}$ between the unit plots. Each plot had 15 plants. Organic amendments and Chemical fertilizers were applied in the field as recommended by Bangladesh Agricultural Research Council (Anonymous, 2005). Healthy seedlings were uprooted from the seedbed and were transplanted in the experimental plots. Immediately after planting, the seedlings were watered. Seedlings were also planted around the experimental field for gap filling.

\section{Preparation of fish and gur fermentation}

For preparing fish and fermented gur(brown sugar), $500 \mathrm{~g}$ gur and $1 \mathrm{~kg}$ small fish mixed properly in a plastic container. Then, the mixed substances kept for 30 days in air tight container for fermentation.

\section{Netting}

For this study the plots of the blocks were covered with net houses measuring $2.50 \mathrm{~m}$ length, $2.0 \mathrm{~m}$ width and $1.50 \mathrm{~m}$ height. 


\section{Treatment application}

The treatments, namely control (only water), Neem oil @ $4 \mathrm{ml} \mathrm{l}^{-1}$ of water at 7 days interval, Mahogany oil @ 4ml 1-1 of water at 7 days interval, Gur fermentation@10 $\mathrm{ml} \mathrm{l}^{-1}$ of water at 7 days interval, Netting, Chlorpyriphos @ 2 $\mathrm{ml} \mathrm{l}^{-1}$ of water at 7 days interval, Emamectin Benzoate @ $1 \mathrm{~g}^{-1}$ of water at 7 days interval and Cartap @ $2 \mathrm{~g} \mathrm{l}^{-1}$ of water at 7 days interval were applied as foliar sprays starting from 35 days after transplanting. Care was taken to avoid drifting of treatment to neighboring plots.No pest control technique was applied in untreated control plots except an equal volume of water, which was used for other plots, was sprayed at 7 days interval.After transplanting of seedlings, weeding, irrigation were accomplished for better growth and development of the plants. After 15 days of transplanting a single healthy seedling per pit was allowed to grow. To support the individual seedling propping was done with bamboo stick and tied them with jute rope.

\section{Harvesting and data collection}

Harvesting of fruits was started from $16^{\text {th }}$ March and continued up to $6^{\text {th }}$ April with an interval of 7 days. Harvesting was usually done manually. In order to observe the effects of the treatments on controlling TFB, data were collected on number and weight of total fruits plot $^{-1}$, number and weight of total healthy fruits plot $^{-1}$, number and weight of total infested fruits plot $^{-1}$, fruits infestation (\%) in number and weight, infestation reduction over control in number and weight, no. of holes and larvae plot ${ }^{-1}$, total yield plot $^{-1}$ and marketable yield plot ${ }^{-1}$, cost of production, gross return and benefit cost ratio (BCR). BCR was calculated by the ratio between gross return of a management practices and total cost of production of those management practices ha ${ }^{-1}$.

\section{Data analysis}

The collected data were analyzed statistically for analysis of variance (ANOVA) with the help of Statistical Tool for Agricultural Research (STAR) 2.0.1 software where the means were separated by Duncan's Multiple Range Test (DMRT).

\section{ResultsandDiscussion}

Effect of management practices on yield by number and weight at first harvest

Total fruits plot ${ }^{-1}$, healthy fruits plot $^{-1}$, infested fruits plot $^{-1}$ and fruits infestation (\%) by number and weight at first harvest (16 March, 2018) were statistically significant (Table 1). The maximum number of total fruits plot $^{-1}(17.00)$ was harvested from $\mathrm{T}_{8}$ treated plot which was statistically similar to $\mathrm{T}_{6}(16.33)$ and $\mathrm{T}_{7}$ (16.00) treated ones. The same treatment produced the highest number (13.00) of healthy fruit plot $^{-1}$ which was statistically similar to that of $T_{6}$ (12.67) treated 
plot. Among the treatments, the highest number of infested fruits plot $^{-1}$ was recorded in $T_{1}(5.00)$ whereas the lowest number of infested fruits plot $^{-1}$ was recorded in $\mathrm{T}_{5}(2.00)$. The fruit infestation was highest in untreated control $\mathrm{T}_{1}$ (38.31\%) plot and the minimum infestation in $\mathrm{T}_{5}(14.76)$ treated plot. The percent fruit infestation reduction over control by Number was the highest in Netting treated plot resulting $61.87 \%$ reduction at first harvest. The maximum weight of total fruits plot $^{-1}(1143.33 \mathrm{~g})$ was obtained from $\mathrm{T}_{8}$ treated plot which was statistically similar to that of $\mathrm{T}_{6}(1116.67 \mathrm{~g})$ treated ones. The same treatment produced maximum weight of healthy fruit plot $^{-1}(864.33 \mathrm{~g})$ which was statistically similar to $\mathrm{T}_{6}(857.67 \mathrm{~g})$ treated ones. Among the treatments, the highest infested fruits plot $^{-1}$ by weight was recorded in $T_{1}(327.00 \mathrm{~g})$ whereas the lowest infested fruits plot $^{-1}$ in weight basis was recorded in $\mathrm{T}_{5}(139.33 \mathrm{~g})$ treated plot. The fruit infestation was highest in untreated control $\mathrm{T}_{1}(40.78 \%)$ plot and the minimum infestation was in $\mathrm{T}_{5}(15.75 \%)$ plot. The percent fruit infestation reduction over control by weight was the highest in Netting treated plot resulting $61.38 \%$ reduction at first harvest.Similar result was observed by Dey et al. (2016) where they obtained the highest number of infested fruits plot $^{-1}$ in untreated control and the lowest number of infested fruits plant ${ }^{-1}$ was recorded in netting treatment.

\section{Effect of management practices on yield by number and weightbasis at second harvest}

Total fruits plot ${ }^{-1}$, healthy fruits plot ${ }^{-1}$, infested fruits plot $^{-1}$ and fruits infestation (\%) by number and weight at second harvest (23 March, 2018) was statistically significant (Table 2). The highest number of total fruits $\operatorname{plot}^{-1}$ (56.00) was observed in $\mathrm{T}_{6}$ treated plot. The same treatment produced the highest number (43.00) of healthy fruit plot $^{-1}$ which was statistically similar to that of $T_{7}$ (41.33) treated plot. Among the treatments, the highest number of infested fruits plot $^{-1}$ was recorded in $T_{1}(17.00)$ treated plot whereas the lowest number of infested fruits plot $^{-1}$ was obtained from $T_{5}$ (3.00) treated plot. The fruit infestation was the highest in untreated control $\mathrm{T}_{1}(42.53 \%)$ plot and the minimum infestation was in $\mathrm{T}_{5}(10.90 \%)$ treated plot. The percent fruit infestation reduction over control by number was the highest in Netting treated plot $\left(\mathrm{T}_{5}\right)$ resulting $73.27 \%$ reduction at second harvest. The maximum weight of total fruits plot $^{-1}(3878.33 \mathrm{~g})$ was recorded in $\mathrm{T}_{6}$ treated plot. The same treatment produced maximum weight of healthy fruit plot $^{-1}(2968.67 \mathrm{~g})$ which was statistically similar to $\mathrm{T}_{7}(2772.33 \mathrm{~g})$ treated plot. Among the treatments, the highest infested fruits plot $^{-1}$ by weight was recorded in $\mathrm{T}_{1}(1049.67 \mathrm{~g})$ treated plot whereas the lowest infested fruits plot $^{-1}$ by weight was recorded in $\mathrm{T}_{5}(199.00 \mathrm{~g})$. The fruit infestation was the highest in untreated control $\mathrm{T}_{1}(42.31 \%)$ plot and the minimum infestation was in $\mathrm{T}_{5}$ $(10.89 \%)$ treated plot. The percent fruit infestation reduction over control by weight was the highest in Netting treated plot resulting $74.26 \%$ reduction at second harvest. Prasannakumar et al. (2013) showed in a study where Neem, 


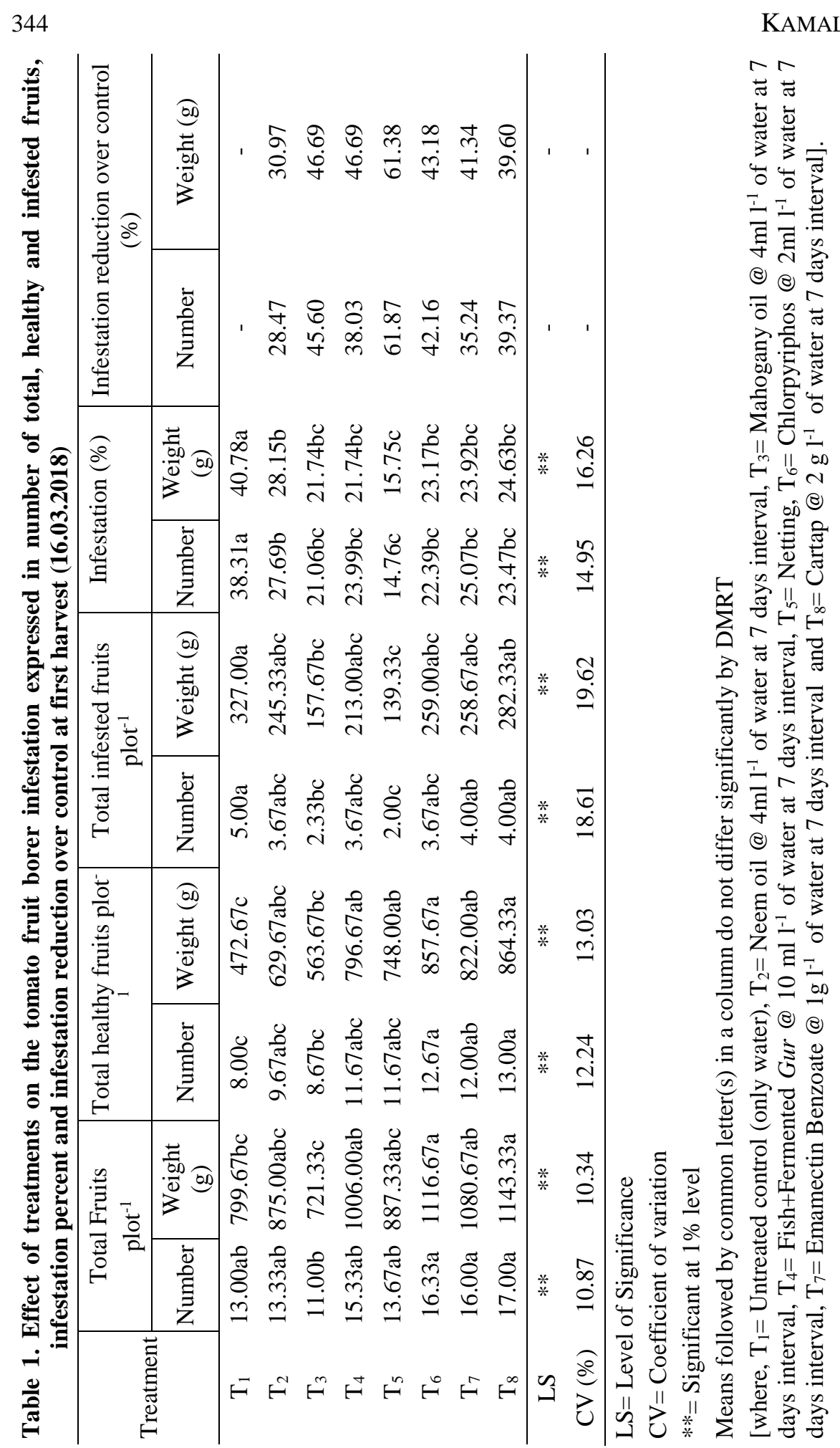




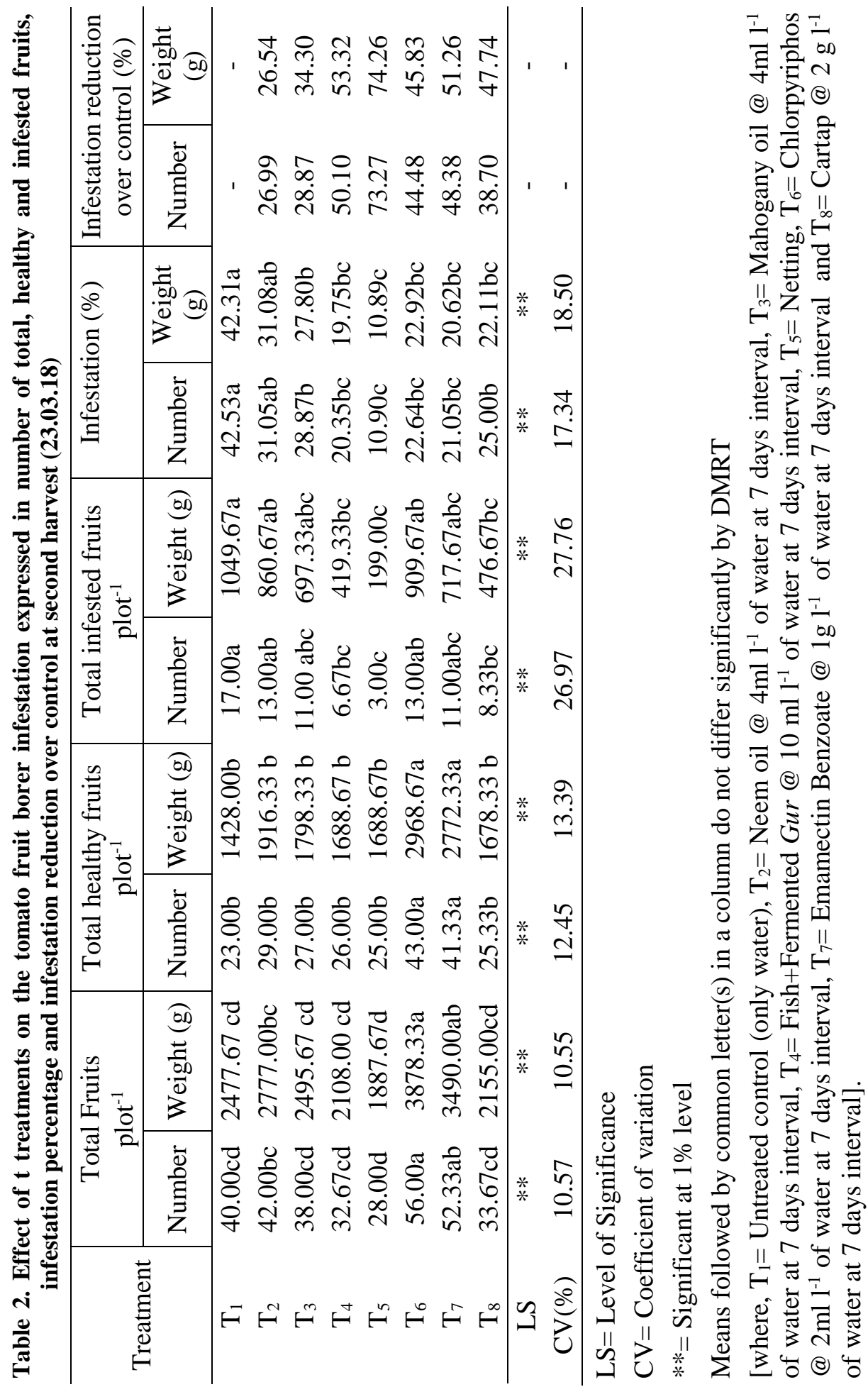


Mahogany and pheromone were found effective in controlling tomato fruit borer but netting treatment was superior. In early fruiting stage, Neem and Mahogany oil were statistically similar in their effectivenessand in mid and late fruiting stage Mahogany oil did not show any significant difference from pheromone whereas netting was significantly different from all others. Present study also showed Mahogany is moderately effective in controlling tomato fruit borer. Majumdar and Powell (2011) also observed that Netting offered 90\% reduction of tomato fruit infestation in the field condition which was almost similar to the present study.

\section{Effect of management practices on yield by number and weight at third harvest}

Total fruits plot ${ }^{-1}$, healthy fruits plot ${ }^{-1}$, infested fruits plot $^{-1}$ and fruits infestation (\%) by number and weight at third harvest (30 March, 2018) was statistically significant (Table 3). The highest number of total fruits plot $^{-1}$ (134.33) was recorded in $T_{1}$ treated plot which was statistically identical to that $\mathrm{T}_{7}$ treated plot. Thehighest number (110.00) of healthy fruit plot $^{-1}$ was harvested from $\mathrm{T}_{7}$ treated plot. Among the treatments, the highest number of infested fruits $\operatorname{plot}^{-1}(59.33)$ was recorded in untreated control plot $\left(\mathrm{T}_{1}\right)$ whereas the lowest number of infested fruits plot $^{-1}$ was obtained from $T_{5}(5.67)$ treated plot. The fruit infestation was the highest in control $\mathrm{T}_{1}(44.05 \%)$ plot and the minimum infestation was in $\mathrm{T}_{5}$ (6.35\%) treated plot. The percent fruit infestation reduction over control by number was the highest in Netting treated plot resulting $84.68 \%$ reduction at third harvest. The maximum weight $(\mathrm{g})$ of total fruits plot $^{-1}$ (8823.33) was harvested from $T_{7}$ treated plot. The same treatment produced maximum weight (7202.67) of healthy fruit plot $^{-1}$. Among the treatments, the highest infested fruits plot $^{-1}$ by weight was recorded in $T_{1}$ (3997.67) untreated plot whereas the lowest infested fruits plot $^{-1}$ by weight was recorded in $\mathrm{T}_{5}$ (338.33) treated plot. The fruit infestation was the highest in untreated control $\left(\mathrm{T}_{1}\right)(46.69 \%)$ and the minimum infestation was in in $\mathrm{T}_{5}(5.41)$ treatment. The percent fruit infestation reduction over control by weight was the highest in Netting treated plot $\left(\mathrm{T}_{5}\right)$ resulting $88.41 \%$ reduction at third harvest. Majumdar et al. (2015) showed that the armyworm and tomato fruit worm caterpillar numbers reduced $98-100 \%$ under net house which was more or less similar to the present findings.

\section{Effect of management practices on yield by number and weight at fourth harvest}

Total fruits plot ${ }^{-1}$, healthy fruits plot ${ }^{-1}$, infested fruits plot $^{-1}$ and fruits infestation (\%) by number and weight at fourth harvest (06 April, 2018) was statistically significant except total fruits plot $^{-1}$ (Table 4). The highest number of total fruits plot $^{-1}$ (114.33) was observed in untreated control plot $\left(T_{1}\right)$ and lowest in $T_{5}$ treated plot. The highest number (96.33) of healthy fruit plot $^{-1}$ was recorded in $\mathrm{T}_{6}$ treated plot which was similar to that of $\mathrm{T}_{7}, \mathrm{~T}_{5}, \mathrm{~T}_{4}$ and $\mathrm{T}_{3}$ treated plot. Among 
the treatments, the highest number of infested fruits plot $^{-1}$ was recorded from untreated control plot $\left(\mathrm{T}_{1}\right)$ (52.33) whereas the lowest number of infested fruits plot $^{-1}$ was recorded in $T_{5}$ (3.00) treated plot. The fruit infestation was highest in untreated control $\left(\mathrm{T}_{1}\right)(46.13 \%)$ plot and the minimum infestation was in $\mathrm{T} 5$ (3.27\%) treated plot. The percent fruit infestation reduction over control by number was the highest in Netting treated plot $\left(\mathrm{T}_{5}\right)$ resulting $92.70 \%$ reduction at fourth harvest. The maximum weight $(\mathrm{g})$ of total fruits plot $^{-1}$ (7531.33) was obtained in $\mathrm{T}_{4}$ treated plot followed by $\mathrm{T}_{3}$ and $\mathrm{T}_{7}$ treatment. The maximum weight (6607.67) of healthy fruit plot $^{-1}$ was recorded from $\mathrm{T}_{6}$. Among the treatments, the highest infested fruits plot $^{-1}$ by weight was recorded in $T_{1}$ (3125.33) treated plot whereas the lowest infested fruits plot $^{-1}$ by weight was recorded in $\mathrm{T}_{5}(210.33)$ treatment. The fruit infestation was highest in untreated control $\mathrm{T}_{1}(45.85 \%)$ plot and the minimum infestation was in $\mathrm{T}_{5}(3.80 \%)$ treated plot. The percent fruit infestation reduction over control by weight basis was the highest in Netting treated plot resulting $91.71 \%$ reduction at fourth harvest. Shah et al. (2013) observed that the effect of different botanicals extracts i.e., Neem seed extract (2.5\%), Turmeric extract (5\%), Henge extract (1.25\%), Garlic extract $(5 \%)$ and insecticide, emamectin benzoate $(0.07 \%)$ were very effective in controlling Helicoverpa armigera infestation in tomato where maximum yield $\left(7540 \mathrm{~kg} \mathrm{ha}^{-1}\right)$ was recorded in Neem seed extract (2.5\%) and percent infestation of larvae of tomato fruit worm was minimum (0.40) in emamectin benzoate treated plot whereas maximum was in untreated control plot.So in terms of environment healthiness point of viewthe neem seed extract was the most promising insecticide for the effective management of tomato fruit worm larvae which was more or less similar to the present findings.

\section{Number of larvae and holesplot ${ }^{-1}$ at different harvest}

The lowest number of larvae plot $^{-1}$ was recorded in netting $(2.00,2.33,3.67$ and 3.00 ) at four different harvests, respectively and the highest number of larvae was recorded from untreated control plot resulting 5.67, 17.33, 56.33 and 48.33 at four harvests, respectively (Table 5). The highest number of fruit holes plot $^{-1}$ was recorded in control plots at all four harvests $(17.33,55.67,181.00$ and 153.00 at $1^{\text {st }}, 2^{\text {nd }}, 3^{\text {rd }}$, and $4^{\text {th }}$ harvest, respectively) and the lowest number of holes was in netting plot at all four harvest $\left(5.00,8.00,15.33\right.$ and 8.67 at $1^{\text {st }}, 2^{\text {nd }}, 3^{\text {rd }}$, and $4^{\text {th }}$ harvest, respectively) (Table 5). Martin et al. (2013) found that the net with finest pore diameter made a strong physical barrier to insect pests that literally disrupted their feeding on tomato fruits resulting in no hole on tomato which was almost similar to present finding. Dutta et al. (2011) found that the botanicals efficiently protected the larval infestation in fruit at different fruiting stages and which was similar to the present findings when botanicals were used as treatment. 


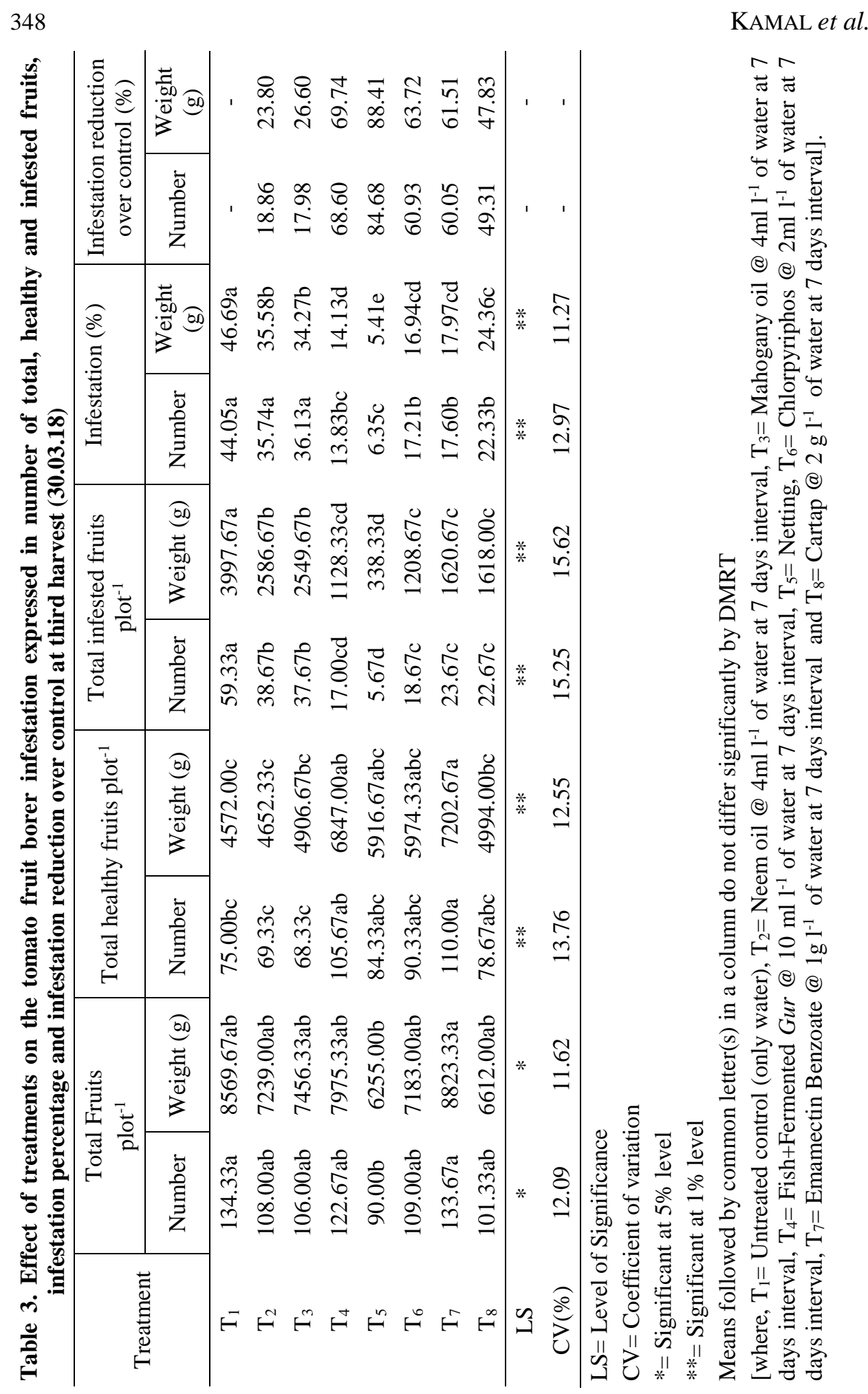




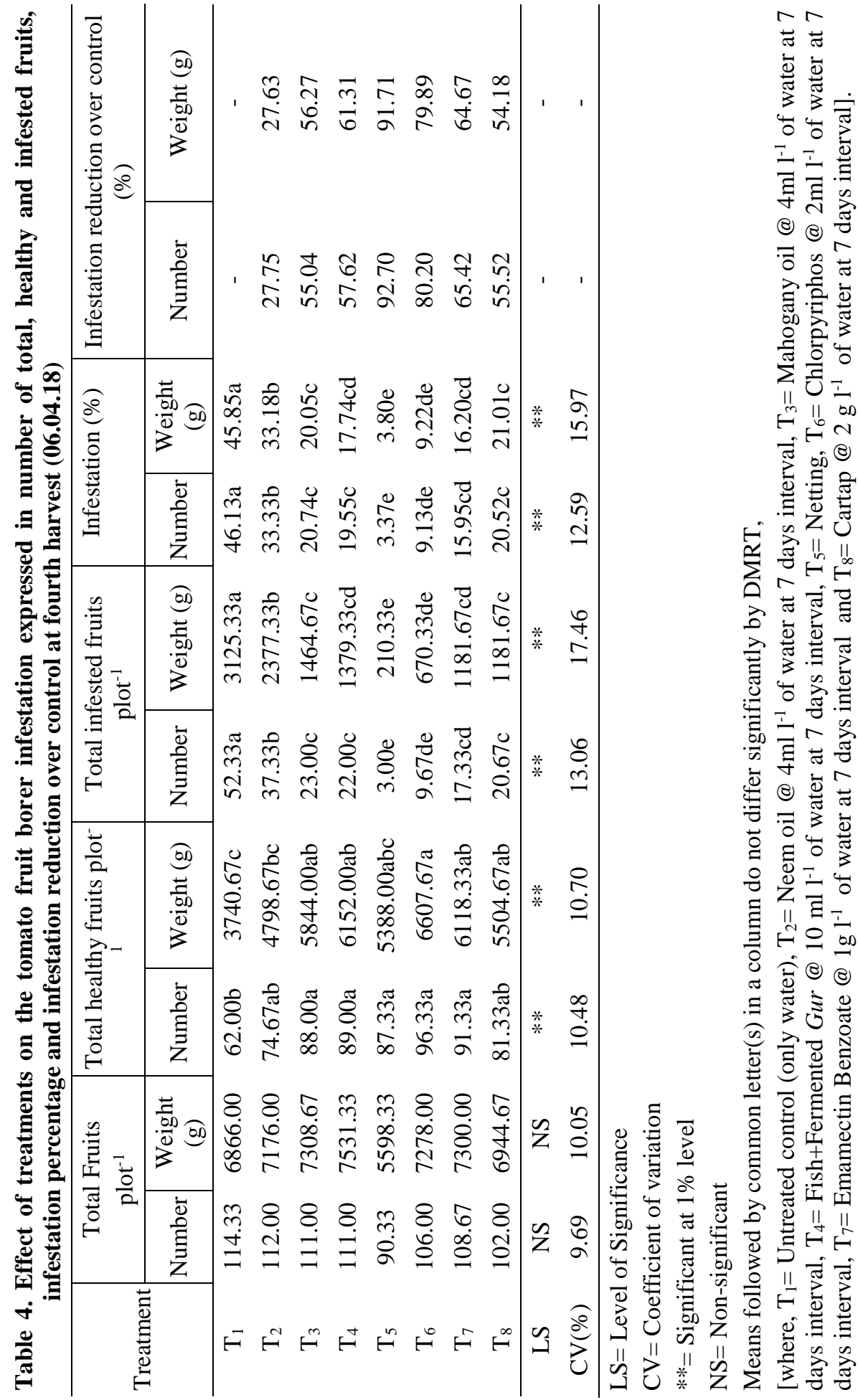




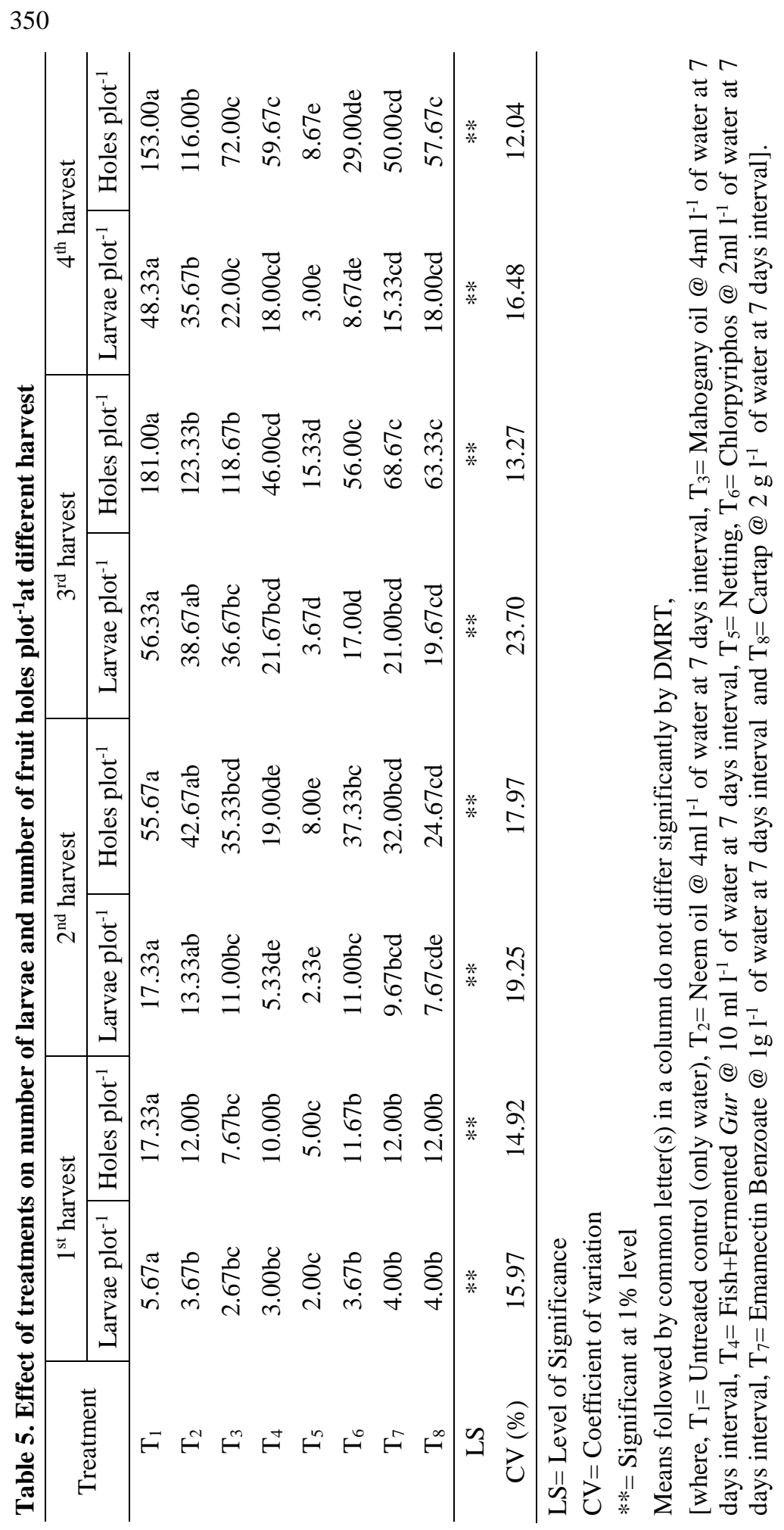

KAMAL $e t a l$. 


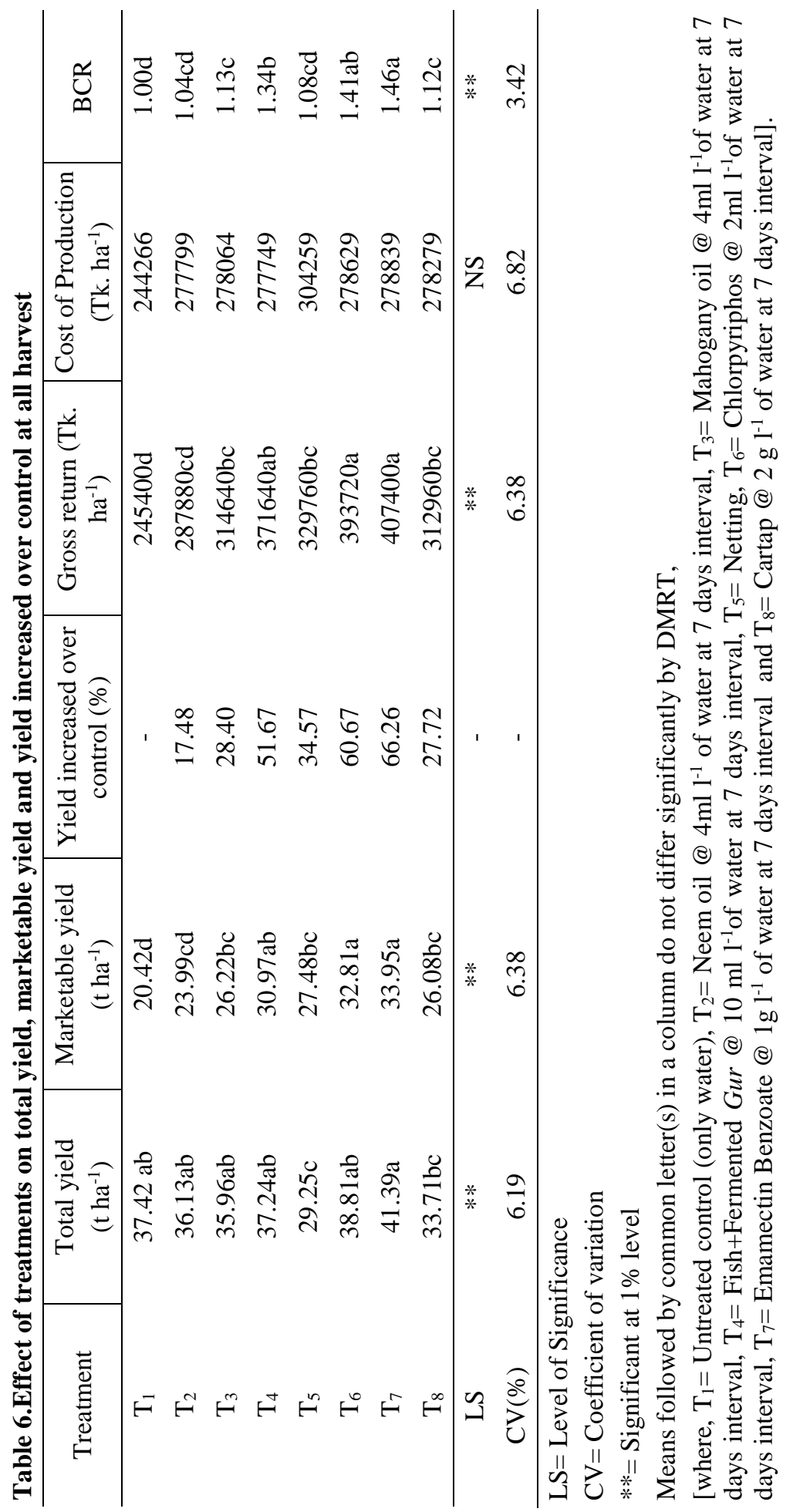




\section{Yield and Benefit Cost Ratio of tomato cultivation}

The yield plot $^{-1}$ showed significant variation among the treatments (Table 6). The highest yield was $\left(33.95 \mathrm{t} \mathrm{ha}^{-1}\right)$ found in T treated plot which was statistically identical to that of $\mathrm{T}_{6}\left(32.81 \mathrm{t} \mathrm{ha}^{-1}\right)$ treated plot.Increased yield over control was highest in $\mathrm{T}_{7}(66.26 \%)$ treatment and the lowest was in $\mathrm{T}_{2}$ treated plot (17.48\%). Material, non-material and overhead cost were recorded for all treatments on unit plot basis and calculated per hectare. The total cost of production ranged between Tk. 244266 and Tk. $304259 \mathrm{ha}^{-1}$. The highest cost of production was found in netting (Tk. $304259 \mathrm{ha}^{-1}$ ) treated plot and the lowest was found in the untreated control (Tk. 244266ha ${ }^{-1}$ ). The range between the gross return was Tk. 245400 ha $^{-}$ ${ }^{1}$ to $\mathrm{Tk} .407400 \mathrm{ha}^{-1}$. The maximum benefit cost ratio was found (1.46) in $\mathrm{T}_{7}$ and the minimum was in untreated control (1.00) plot.

\section{Conclusion}

The findings of the present study revealed that all the management practices namely Neem oil, Mahogany oil, Fish + Fermented Gur, Netting, Chlorpyriphos, Emamectin Benzoate and Cartap had considerable action against the tomato fruit borer, of which Netting showed the highest performance in reducing infestation over control compared to other management practices. Emamectin Benzoatewas found highly effective against tomato fruit borer and provided higher economic yield.

\section{Acknowledgement}

The financial assistance of Khulna University Research Cell (KURC), Khulna, Bangladesh to carry out the research work is thankfully acknowledged.

\section{References}

Anonymous. 2005. Fertilizer Recommendation Guide. Bangladesh Agricultural Research Council (BARC). New Airport Road, Farmgate, Dhaka 1215.

BBS (Bangladesh Bureau of Statistics). 2017. Statistical Year Book of Bangladesh. Statistical Division Ministry of Planning, Govt. People's Republic of Bangladesh, Dhaka.

Bose, T. K. and M. G. Som. 1990. Vegetable crops in India, Naya Prokash, 206, Bidhan Sarani, Calcutta, India. p. 249.

Dey, M., S. Das, M. M. Kamal and R. Sarkar. 2016. Performance of different management practices on tomato fruit borer, (Helicoverpa armigera Hubner) abundance and infestation. J. Bangladesh Agric. Univ. 14(2): 161-166.

Dutta, P., A. K. Singha, P. Das and S. Kalita. 2011.Management of brinjal fruit and shoot borer, Leucinodes orbanalis Guenee in agro-ecological condition of West Tripura. Schol. J. Agric. Sci.1(2): 16-19.

FAOSTAT. 2001. FAO Statistical Databases. Food \& Agriculture Organization of the United Nations. Rome, Italy. 
Friedman, M. 2013. Anticarcinogenic, Cardioprotective, and Other Health Benefits of Tomato Compounds Lycopene, $\alpha$-Tomatine, and Tomatidine in Pure Form and in Fresh and Processed Tomatoes. J. Agric. Food Chem.61:9534-9550. http://dx.doi.org/10.1021/jf402654e

Geiger, F., J. Bengtsson, F. Berendse, W.W. Weisser, M. Emmerson, M.B. Morales, P. Ceryngier, J. Liira, T. Tscharntke, C. Winqvist and S. Eggers. 2010. Persistent negative effects of pesticides on biodiversity and biological control potential on European farmland. Basic Appl. Ecol. 11: 97-105.

Hossain, M.M., Khalequzzaman, K.M., Hossain, M.A., Mollah, M.R.A. and M.A. Siddique. 2004. Influence of planting time on the extension of picking period of four Tomato varieties. J. Biol. Sci. 4: 616- 619.

Karabhantanal, S. and J. Awaknavar. 2013. Bio intensive approach for the management of tomato fruit borer, Helicoverpa armigera (Hubner). Pest Manag. Hort. Ecosys. 18: $135-138$.

Majumdar, A. and M. Powell. 2011. Net House Vegetable Production: Pest Management Successes and Challenges. J. Natl. Assoc. Country Agric. Agents.4(1): 355-363.

Majumdar, A., Chambliss, A., Mastin, W. and S. Carpenter. 2015. High Tunnel Pest Exclusion System: Laboratory and Field Experiences. J. Natl. Assoc. Country Agric. Agents. 8(1).https://www.nacaa.com/journal/index.php?jid=487

Martin, T., Palix, R., Kamal, A., Delétré, E., Bonafos, R., Simon. S. and M. Ngouajio. 2013. A repellent net as a new technology to protect cabbage crops. J. econ. entomol.106: 1699-1706.

Pedro, A. M. and M. M. Ferreira. 2007. Simultaneously calibrating solids, sugars and acidity of tomato products using PLS2 and NIR spectroscopy. Analytica Chimica Acta. 595(1-2): 221-227.

Prasannakumar, N., A. Chakravarthy and L.V. Kumar. 2013. Relationship between pheromone trap catches and field damage of selected lepidopterous pests on vegetable crops. Pest Manag. Hort. Ecosys.15: 63-67.

Shah, J., M. Inayatullah, K. Sohail, S. Shah, T. Iqbal and M. Usman. 2013. Efficacy of botanical extracts and a chemical pesticide against tomato fruit worm, Helicoverpa armigera (Lepidoptera: Noctuidae). Sarhad J. Agric. 29: 93-96.

Wagh, S., P. Patil, S. Lad and S. Patil. 2012. Eco-friendly management of tomato pests. Int. J. Plant Protec.5: 45-48. 
